TITLE:

\title{
Nematode Diversity at Thachin River Mouth, Samut Sakhon, Thailand
}

\section{$\operatorname{AUTHOR}(S)$ :}

SAWANGARRERUKS, SUCHAT; YAOWASOOTH, PATCHARAPORN; POOVACHIRANON, SOMBAT

\section{CITATION:}

SAWANGARRERUKS, SUCHAT ... [et al]. Nematode Diversity at Thachin River Mouth, Samut Sakhon, Thailand. Publications of the Seto Marine Biological Laboratory 2011, 41: 25-34

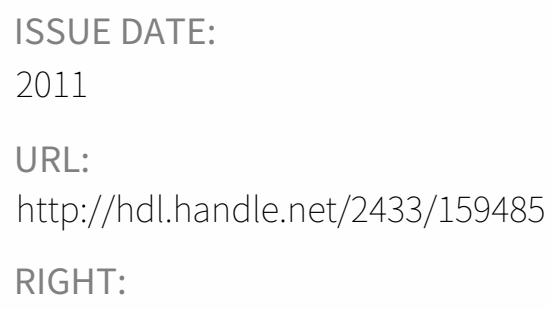




\title{
Nematode Diversity at Thachin River Mouth, Samut Sakhon, Thailand
}

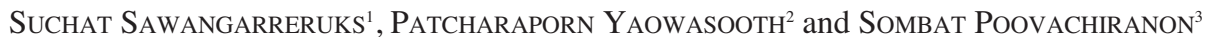

\author{
Marine and Coastal Resources Research Center (the Upper Gulf of Thailand) \\ 120/1 Bangyapreak 6, Mueang, Samut Sakhon 74000, Thailand \\ e-mail address: 'suchat58@hotmail.com (Corresponding author, Tel. +66 3449-7073; Fax. +66 3449-7074), \\ 2ao_zeza@hotmail.com, ${ }^{3} \mathrm{pmbc} @ 1$ loxinfo.co.th
}

\begin{abstract}
Nematode communities were investigated in January and June 2008 at the western Thachin River mouth, Samut Sakhon, Thailand. The sampling site is comprised of two different habitats, i.e. mangrove forest characterized by Avicennia marina and mudflat adjacent to the mangrove forest. Mean densities of the nematode ranged from $110-995$ ind.10 $\mathrm{cm}^{-2}$ while taxonomic classification showed 32 and 50 genera in the mudflat and mangrove forest, respectively. The high diversity indices of nematode assemblages were recorded in both habitats with values ranged between $0.49-2.32$ in mudflat and $2.02-2.92$ in mangrove. The predominant genera were Terschellingia sp. Daptonema sp. Sabatieria sp. and Hopperia sp. Two distinct groups of nematode communities between the two habitats were detected by multidimensional scaling, analyses of similarity percentages. The number of species and density were significantly different in the two different habitats $(p<0.05)$. The mangrove forest provided wide variety of microhabitat and physically stable environment while the mudflat area was exposed to water turbulence and prone to anthropogenic activities. The environmental differences of the two communities may have resulted in higher diversity and density of nematodes in the mangrove forest.
\end{abstract}

Key words: nematode, mudflat, mangrove, Thachin River, Samut Sakhon

\section{Introduction}

There are four main rivers that discharge freshwater and sediments into the upper gulf of Thailand. Estuary area of the upper gulf of Thailand was surrounded by mangroves and mudflats. This area currently suffers from anthropogenic activities on land that are, one way or another, harmful to marine habitats, and man-made pollutions, such as effluents from urban communities, aquacultures, and the expansion of accommodation for industry, became severe threat to coastal habitat. Deterioration of water quality, eutrophication and organic enriched sediments have impacted fishery resources and marine ecosystems including benthic communities. The nematodes are tiny invertebrates which generally occur in the greatest number in the top $5 \mathrm{~cm}$ of sediment and usually are living in the interstitial sediment. Nematodes play a major role in nutrient mineralization and are also potential foods in the food web. In addition, nematode distributions are pollution bioindicator and a key group for environmental assessment (Alongi et al., 1983; Mirto et al., 2002).

Biological investigation is an important tool to pursue environmental changes. As experienced, benthic community structure is proved to be a major component in ecosystem responding rapidly to environmental change and human impact (Harkantra, 1982; Tsutsumi, 1987, 1990). This study therefore aims to investigate the nematode community structures in two different habitats as well as to establish baseline information of benthic community structure in this area where anthropogenic activities keep growing continuously. 


\section{Materials and Methods}

\section{Study sites:}

Thachin River is located on the western part of the upper gulf of Thailand. The intertidal zone of the river mouth comprises of two different ecosystems, i.e. mudflat and mangrove (Fig. 1). The mangrove forest is dominated by Avicennia marina and A. alba. Widespread mudflat can be observed during ebb tide, which is the important area for foraging waterbirds, both passage and winterbirds species, and resident waterbirds (Round, 2006). The Gulf of Thailand is influenced by two distinct monsoons, i.e. southwest monsoon (wet season) and northeast monsoon (dry season). The monsoon causes great fluctuations in the physical and chemical parameters.

\section{Sampling procedures:}

Four stations are selected in mangrove and mudflat areas. Nematode collection in both areas was carried out in January (represented northeast monsoon) and June (represented southwest monsoon) in 2008. Eight sampling stations were located parallel to the river bank with approximate distance of 150 - $350 \mathrm{~m}$ between the stations. Four sampling stations were located in the mudflat habitat and the others in the mangrove habitat (Fig. 1).

Nematode samples were collected with a $3 \mathrm{~cm}$ diameter syringe to a depth of $5 \mathrm{~cm}$. Four sampling replicates were collected at each station, and two sub-samples inside of each replicate were collected during the lowest tide of spring period (Fig. 2). Nematode samples were preserved in 4 percent formaldehyde, later identified to as a low taxonomic level as possible and counted at the laboratory.

\section{Data analyses:}

Species diversity $\left(H^{\prime}\right)$ index and Pielou's evenness $\left(J^{\prime}\right)$ index of nematode community structures

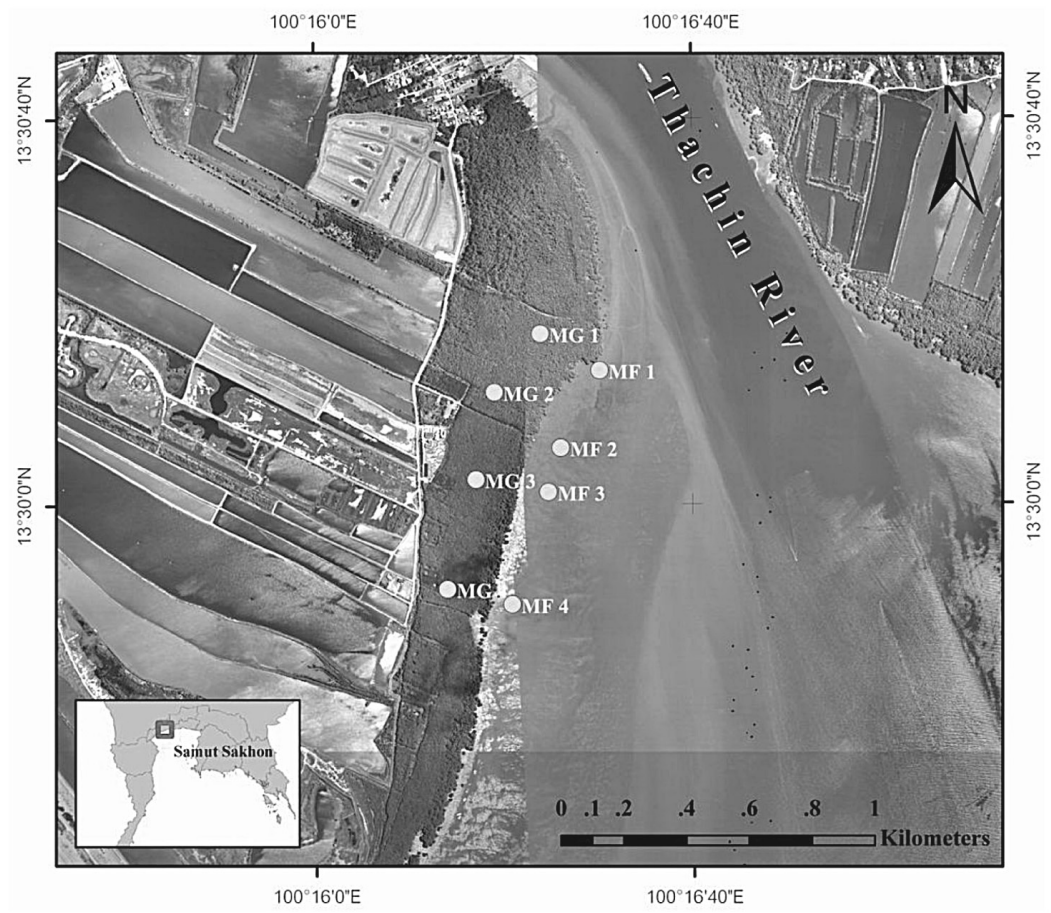

Fig. 1. Map showing eight sampling stations in the mudflat and mangrove habitat, western Thachin River mouth, Samut Sakhon, Thailand. 


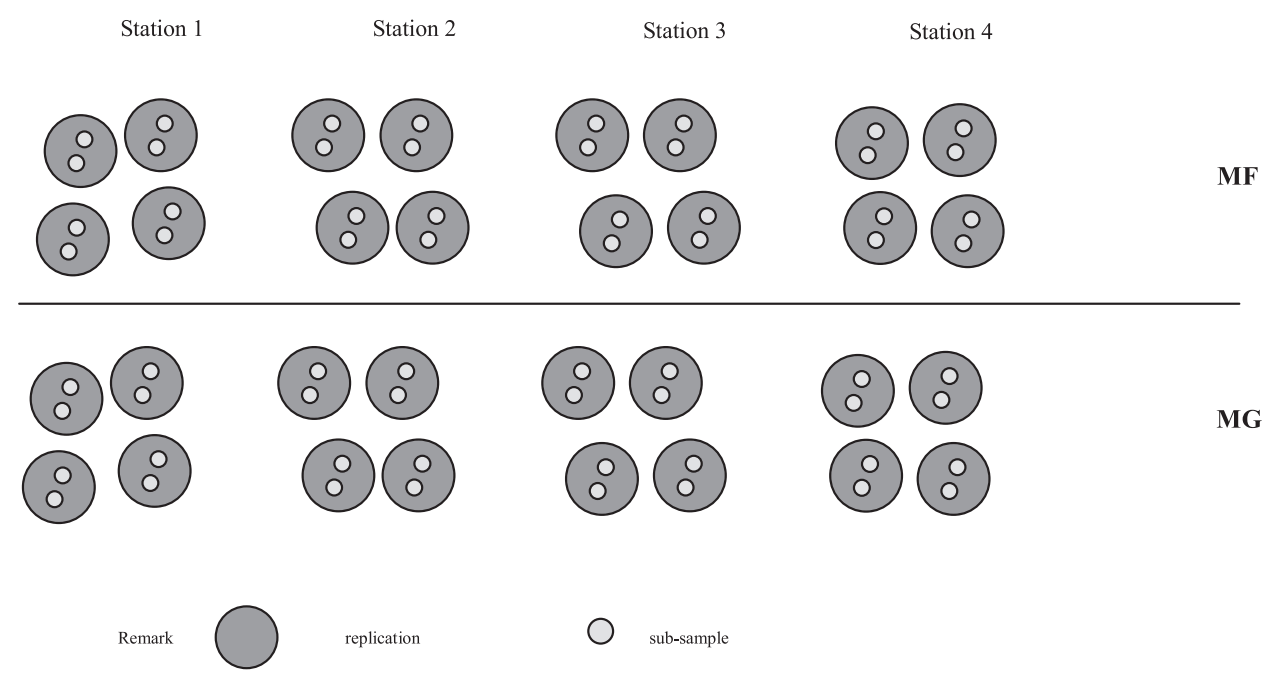

Fig. 2. Nematode sampling method in mudflat (MF) and mangrove (MG) at the western Thachin River mouth, Samut Sakhon.

were determined. Analysis of Variance (ANOVA) was carried out to test the difference in nematode density and the number of species between habitats and seasonal periods. Multidimensional Scaling (MDS) was used to analyse nematode community structure by ordination to identify group in the community structure over space and time. The number of nematode was $\log (x+1)$ transformed. Cluster analysis dendrogram of Bray-Curtis similarity measure was used to determine similarity in the nematode community structure between different stations.

\section{Results}

\section{Composition and Distribution of Nematode}

At least 52 genera in 21 families of nematode were present at the western Thachin river mouth, Samut Sakhon. Higher number of nematode was found in the mangrove area than the mudflat area, 50 genera in 21 families and 32 genera in 18 families, respectively. Higher mean total density occurred in the mangrove habitat, 522 ind. $10 \mathrm{~cm}^{-2}$, than mudflat habitat, 430 ind. $10 \mathrm{~cm}^{-2}$. The nematode communities were dominated by Terschellingia sp., Daptonema sp., Sabatieria sp., and Hopperia sp. Other genera were scarce. Although the means of nematode abundance were different between the two sampling habitats (Table 1 and Fig. 3), statistical analysis indicated non-significant difference in the density of nematode. However, the number of species was significantly different $(p<0.05)$ between the two habitats. Some nematodes genera were found in specific areas. For example, Syringgolaimus sp. and Linhmoeus sp. were found in mudflat habitat while Wieseria sp., Adoncholaimus sp., Longicyatholaimus sp., Desmolaimus sp. and Disconema sp. were in the mangrove habitat (Appendix 1).

Mudflat: At least 32 genera in 18 families were present. They are listed in Appendix 1. The mean total density, $430 \pm 64$ ind. $10 \mathrm{~cm}^{-2}$, was higher in the wet season, 570 ind. $10 \mathrm{~cm}^{-2}$, than the dry season, 289 ind $10 \mathrm{~cm}^{-2}$. The number of species and density of the nematode were significantly different $(p<0.05)$ between the two seasons. Station MF1 and MF2 showed high mean total density (Fig. 3). Terschellingia sp. Daptonema sp1. and Sabatieria sp. dominated the mudflat area where they consisted of more than $70 \%$ of the total number. 
Table 1. The mean, minimum and maximum number of species, diversity index $\left(H^{\prime}\right)$ and evenness index $\left(J^{\prime}\right)$ of nematode in two different habitats at the western Thachin River mouth, Samut Sakhon.

\begin{tabular}{|c|c|c|c|c|c|c|c|}
\hline & & \multicolumn{2}{|c|}{ Number of species } & \multicolumn{2}{|c|}{ Diversity index } & \multicolumn{2}{|c|}{ Evenness index } \\
\hline & & mudflat & mangrove & mudflat & mangrove & mudflat & mangrove \\
\hline \multirow{3}{*}{ January } & mean & 11 & 23 & 1.86 & 2.56 & 0.64 & 0.88 \\
\hline & $\min$. & 8 & 16 & 1.47 & 2.02 & 0.50 & 0.72 \\
\hline & $\max$ & 14 & 31 & 2.32 & 2.87 & 0.80 & 0.98 \\
\hline \multirow{3}{*}{ June } & mean & 10 & 25 & 1.19 & 2.51 & 0.41 & 0.86 \\
\hline & $\min$. & 3 & 20 & 0.49 & 2.11 & 0.17 & 0.72 \\
\hline & $\max$ & 19 & 28 & 1.69 & 2.92 & 0.58 & 1.00 \\
\hline \multicolumn{2}{|c|}{ two way ANOVA } & \multicolumn{2}{|c|}{$p>0.05$} & \multicolumn{2}{|c|}{$p<0.05$} & \multicolumn{2}{|c|}{$p<0.05$} \\
\hline
\end{tabular}

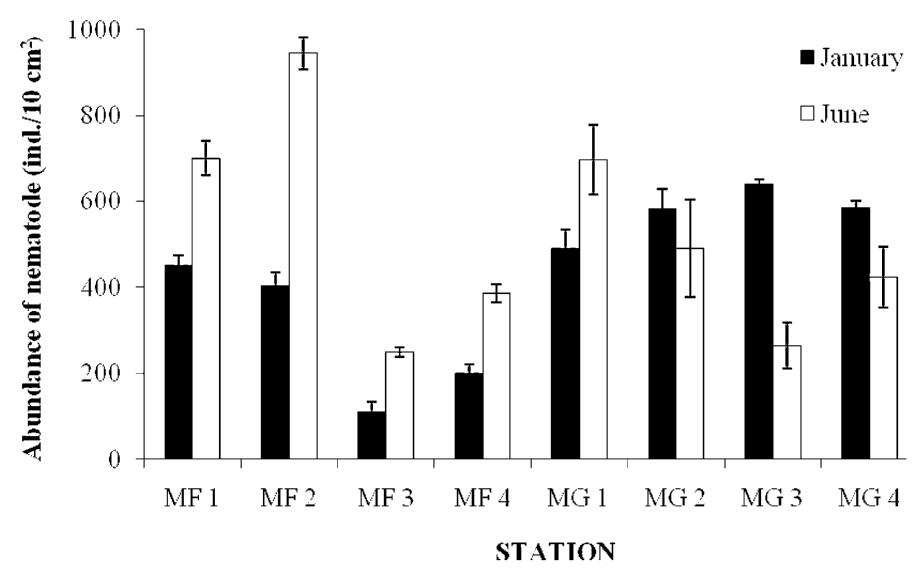

Fig. 3. Variation and mean $( \pm S D)$ of nematode density (ind. $10 \mathrm{~cm}^{-2}$ ) analyzed at the western Thachin River mouth, Samut Sakhon.

In January, the mudflat habitat contained more diverse nematode taxa than in June ( 25 genera in 15 families). Among the four stations, variation in the number species ranged between $8-14$ genera (Table 1). Mean total density was $289 \pm 34$ ind. $10 \mathrm{~cm}^{-2}$. High density was observed at station MF1 followed by station MF2, MF4 and MF3, respectively (Table 1). The predominant nematode was Terschellingia sp. which was found in all stations, followed by Daptonema sp1. and Hopperia sp.

The lowest number of taxa was observed in June (Fig. 3). The nematode composition was similar to in January with 24 genera in 15 families, and the number of genera ranged between 3 - 19 (Table 1). The highest density was observed at station MF2, followed by station MF1 MF4 and MF3, respectively (Fig. 3). Mean total density was recorded $570 \pm 86$ ind. $10 \mathrm{~cm}^{-2}$. Daptonema sp1. Terschellingia sp. and Sabatieria sp. were dominant in June.

Mangrove: Spatial and temporal distribution of nematode revealed 50 genera in 21 families (Appendix 1). Taxonomic compositions were significantly different between the two seasons $(p<$ $0.05)$. Higher density of nematode was observed in the dry season than in the wet season. The mean 
Appendix 1. List of nematode taxa were found in mudflat and mangrove habitats at Thachin River mouth, Samut Sakhon, in January and June 2008. (x = presented)

\begin{tabular}{|c|c|c|c|c|c|c|}
\hline \multirow{2}{*}{$\underline{\text { Order }}$} & \multirow{2}{*}{$\underline{\text { Family }}$} & \multirow{2}{*}{$\underline{\text { Species }}$} & \multicolumn{2}{|c|}{ Mudflat } & \multicolumn{2}{|c|}{$\underline{\text { Mangrove }}$} \\
\hline & & & January & June & January & June \\
\hline \multirow[t]{11}{*}{ Enoplida } & Anoplostomidae & Anoplostoma sp. & & $\mathrm{x}$ & $\mathrm{x}$ & $\mathrm{x}$ \\
\hline & Anticomidae & Anticoma sp. & & $\mathrm{x}$ & $\mathrm{x}$ & \\
\hline & Ironidae & Syringolaimus sp. & $\mathrm{x}$ & & & \\
\hline & & Trissonchulus sp. & & & $\mathrm{x}$ & $\mathrm{x}$ \\
\hline & Leptosomatidae & Metacylicolaimus sp. & & & & $\mathrm{x}$ \\
\hline & Oxystominidae & Halalaimus sp. & $\mathrm{x}$ & $\mathrm{x}$ & $\mathrm{x}$ & $\mathrm{x}$ \\
\hline & & Oxystomina sp. & & $\mathrm{x}$ & $\mathrm{x}$ & $\mathrm{x}$ \\
\hline & & Wieseria sp. & & & $\mathrm{x}$ & \\
\hline & Oncholaimidae & Adoncholaimus sp. & & & $\mathrm{x}$ & \\
\hline & & Metoncholaimus sp. & & & $\mathrm{x}$ & \\
\hline & & Viscosia $\mathrm{sp}$ & $\mathrm{x}$ & $\mathrm{x}$ & $\mathrm{x}$ & $\mathrm{x}$ \\
\hline \multirow[t]{44}{*}{ Chormadorida } & Chormadoridae & Chromadora sp. & $\mathrm{x}$ & $\mathrm{x}$ & $\mathrm{x}$ & $\mathrm{x}$ \\
\hline & & Neochromadora sp. & & $\mathrm{x}$ & $\mathrm{x}$ & $\mathrm{x}$ \\
\hline & & Prochromadora sp. & & $\mathrm{x}$ & & $\mathrm{x}$ \\
\hline & & Ptycholaimellus sp. & $\mathrm{x}$ & $\mathrm{x}$ & $\mathrm{x}$ & $\mathrm{x}$ \\
\hline & Comesomatidae & Laimella sp. & & & & $\mathrm{x}$ \\
\hline & & Hopperia sp. & $\mathrm{x}$ & $\mathrm{x}$ & $\mathrm{x}$ & $\mathrm{x}$ \\
\hline & & Perrickia sp. & $\mathrm{x}$ & & $\mathrm{x}$ & \\
\hline & & Sabatieria sp. & $\mathrm{x}$ & $\mathrm{x}$ & $\mathrm{x}$ & $\mathrm{x}$ \\
\hline & Ethmolaimidae & Neotonchus sp. & $\mathrm{x}$ & & $\mathrm{x}$ & \\
\hline & Cyatholaimidae & Kraspedonema sp. & & & $\mathrm{x}$ & \\
\hline & & Longicyatholaimus sp. & $\mathrm{x}$ & & $\mathrm{x}$ & \\
\hline & & Nannolaimoides $\mathrm{sp}$. & & & $\mathrm{x}$ & $\mathrm{x}$ \\
\hline & & Paralongicyatholaimus sp. & $\mathrm{x}$ & $\mathrm{x}$ & $\mathrm{x}$ & $\mathrm{x}$ \\
\hline & Selachinematidae & Halichoanolaimus sp. & & & $\mathrm{x}$ & $\mathrm{x}$ \\
\hline & & Synonchiella sp. & & & $\mathrm{x}$ & \\
\hline & Desmodoridae & Desmodora sp. & $\mathrm{x}$ & $\mathrm{x}$ & $\mathrm{x}$ & $\mathrm{x}$ \\
\hline & & Metachromadora sp. & $\mathrm{x}$ & $\mathrm{x}$ & $\mathrm{x}$ & $\mathrm{x}$ \\
\hline & & Metadesmodora sp. & & & & $\mathrm{x}$ \\
\hline & & Paradesmodora sp. & & & $\mathrm{x}$ & \\
\hline & & Spirinia sp. & & & & $\mathrm{x}$ \\
\hline & Microlaimidae & Chromaspirina sp. & & & $\mathrm{x}$ & $\mathrm{x}$ \\
\hline & & Microlaimus sp. & & $\mathrm{x}$ & $\mathrm{x}$ & $\mathrm{x}$ \\
\hline & Leptolaimidae & Antomicron sp. & & & $\mathrm{x}$ & \\
\hline & & Camacolaimus sp. & $\mathrm{x}$ & & $\mathrm{x}$ & $\mathrm{x}$ \\
\hline & & Leptolaimoides sp. & & & & $\mathrm{x}$ \\
\hline & & Leptolaimus sp. & & $\mathrm{x}$ & & $\mathrm{x}$ \\
\hline & & Procamacolaimus sp. & & & $\mathrm{x}$ & $\mathrm{x}$ \\
\hline & Haliplectidae & Haliplectus sp. & $\mathrm{x}$ & & $\mathrm{x}$ & $\mathrm{x}$ \\
\hline & Aegialoalaimidae & Aegialoalaimus sp. & $\mathrm{x}$ & $\mathrm{x}$ & $\mathrm{x}$ & $\mathrm{x}$ \\
\hline & Desmoscolecidae & Desmolorenzia sp. & & & $\mathrm{x}$ & \\
\hline & & Desmoscolex sp. & & & $\mathrm{x}$ & $\mathrm{x}$ \\
\hline & Xyalidae & Daptonema sp.1 & $\mathrm{x}$ & $\mathrm{x}$ & $\mathrm{x}$ & $\mathrm{x}$ \\
\hline & & Daptonema sp. 2 & $\mathrm{x}$ & $\mathrm{x}$ & $\mathrm{x}$ & $\mathrm{x}$ \\
\hline & & Daptonema sp.3 & $\mathrm{x}$ & $\mathrm{x}$ & & $\mathrm{x}$ \\
\hline & & Daptonema sp.4 & $\mathrm{x}$ & $\mathrm{x}$ & & $\mathrm{x}$ \\
\hline & & Linhystera sp. & $\mathrm{x}$ & & & $\mathrm{x}$ \\
\hline & & Theristus sp. & $\mathrm{x}$ & $\mathrm{x}$ & $\mathrm{x}$ & $\mathrm{x}$ \\
\hline & Sphaerolaimidae & Sphaerolaimus sp. & $\mathrm{x}$ & $\mathrm{x}$ & $\mathrm{x}$ & $\mathrm{x}$ \\
\hline & Linhomoeidae & Desmolaimus sp. & $\mathrm{x}$ & & $\mathrm{x}$ & \\
\hline & & Disconema sp. & & & $\mathrm{x}$ & \\
\hline & & Linhomoeus sp. & $\mathrm{x}$ & $\mathrm{x}$ & & \\
\hline & & Metalinhomoeus sp. & $\mathrm{x}$ & $\mathrm{x}$ & $\mathrm{x}$ & $\mathrm{x}$ \\
\hline & & Terschellingia sp. & $\mathrm{x}$ & $\mathrm{x}$ & $\mathrm{x}$ & $\mathrm{x}$ \\
\hline & Axonolaimidae & Parodontophora sp. & $\mathrm{x}$ & $\mathrm{x}$ & $\mathrm{x}$ & $\mathrm{x}$ \\
\hline \multicolumn{3}{|c|}{ Freshwater Nematode } & & & $\mathrm{x}$ & $\mathrm{x}$ \\
\hline & Unknown 1 & & & & $\mathrm{x}$ & \\
\hline & Unknown 2 & & & & $\mathrm{x}$ & \\
\hline
\end{tabular}


total densities were $522 \pm 27$ ind. $10 \mathrm{~cm}^{-2}$. The highest density was observed at station MG1 followed by stations MG2, MG3 and MG4. The dominant nematodes were Anoplostoma sp., Terschellingia sp., Sabatieria sp., Haliplectus sp. and Desmodora sp. which shared 55 percent of total nematode.

In January, the mangrove habitat contained the most diverse nematode taxa, 45 genera in 20 families. The number of genera varied between 16 - 31 (Table 1). The mean total density was $575 \pm 26$ ind. $10 \mathrm{~cm}^{-2}$ (Fig. 3). The result indicated that station MG3 had the highest density followed by MG4, MG2 and MG1, respectively. The dominant nematodes were Terschellingia sp., Sabatieria sp., Anoplostoma sp., Trissonchulus sp. and Desmodora sp., respectively.

In June, the nematodes consisted of 37 genera in 19 families, and the number of species ranged between 20 - 28 genera (Table 1). The mean total densities were $469 \pm 29$ ind. $10 \mathrm{~cm}^{-2}$. Station MG1 contained the highest mean total density, followed by station MG2, MG4 and MG3, respectively (Fig. 3). The dominant species were Anoplostoma sp., Sabatieria sp. Haliplectus sp. and Terschellingia sp.

\section{Number of species, diversity and evenness}

2.1 The number of species: Variation in the number of species occurred in both sampling sites and seasons. The mudflat habitat had more fluctuation between seasons than mangrove habitat (Table 1). However, the number of species in the mudflat habitat was less than that in the mangrove habitat. Although the fluctuation difference in the number of species between the two seasonal periods of each habitat was recorded, ANOVA indicated no significant difference.

2.2 Diversity index $(H)$ : Most of the diversity indices at each station of the two habitats showed high values. The highest mean diversity index was recorded in the dry season while the lowest value was observed in the wet season at the mudflat habitat. Fluctuation of the diversity index was similar to the number of species with broad difference in the mudflat area and narrow difference in the mangrove area (Table 1$)$. ANOVA tests showed significant differences $(p<0.05)$ both between habitats and between seasons.

2.3 Pielou's evenness index $\left(J^{\prime}\right)$ : High mean values were observed in both areas in the dry season. The evenness index was relatively poor in the mudflat area with values ranged between $0.17-0.80$ in two seasons. The high index value was observed in the mangrove habitat with narrow ranges between the two seasons (Table 1). Both the mudflat and mangrove areas showed significant difference in evenness index $(p<0.05)$ between the two seasonal periods.

\section{Community Structure of Nematode}

Nematode community structures between the two different habitats were analyzed by multivariate analyses which estimated cluster pattern and MDS. MDS ordination clearly pointed out the presence of two different nematode communities which were in the mangrove and mudflat habitats (Fig. 4). The cluster analysis by Bray-Curtis Similarity also showed the same pattern of the two groups at 50 percent similarity (Fig. 5).

\section{Discussion and Conclusion}

\section{Composition and Distribution}

Density of the nematode manifests difference in the station and seasonal periods, ranging between 231 - 970 ind. $10 \mathrm{~cm}^{-2}$. Composition and abundance of the soft-bottom benthic assemblages, including nematodes, could be influenced by physical, chemical and biological factors such as salinity, temperature, grain size, organic matters, current speed, predation as well as interspecific competition. These factors can be vital for the survival of benthic animals, and they may also influence each other. Particularly in tropical zone, it is difficult to pinpoint factors which control abundance and distribution. (Alongi, 1990; Chou et al. 2004; Talawat et al. 2004). Unfortunately environmental factors were not available in this study. 


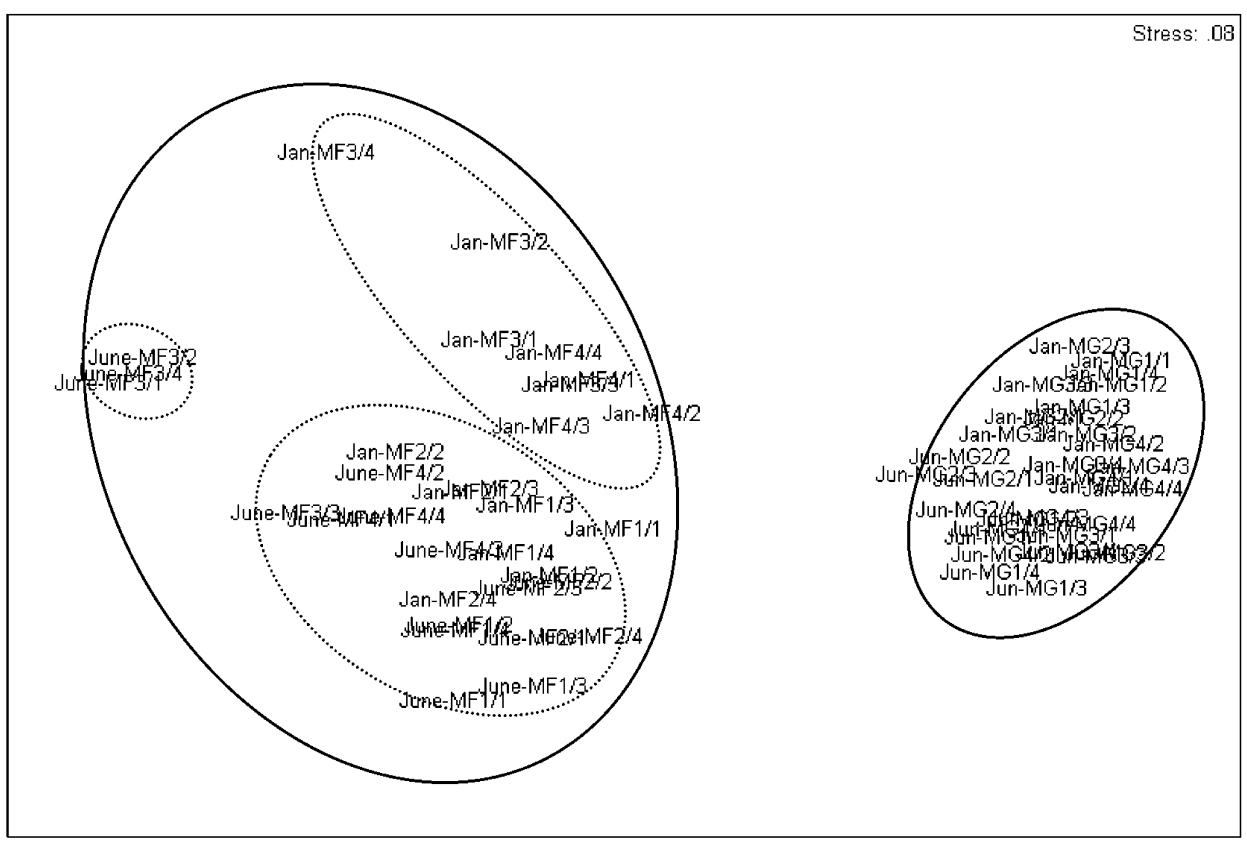

Fig. 4. The number of species and density of nematode at the western Thachin River mouth, Samut Sakhon, were analyzed by Multi-dimension scaling (MDS) on $\ln (\mathrm{x}+1)$ transformed abundances.

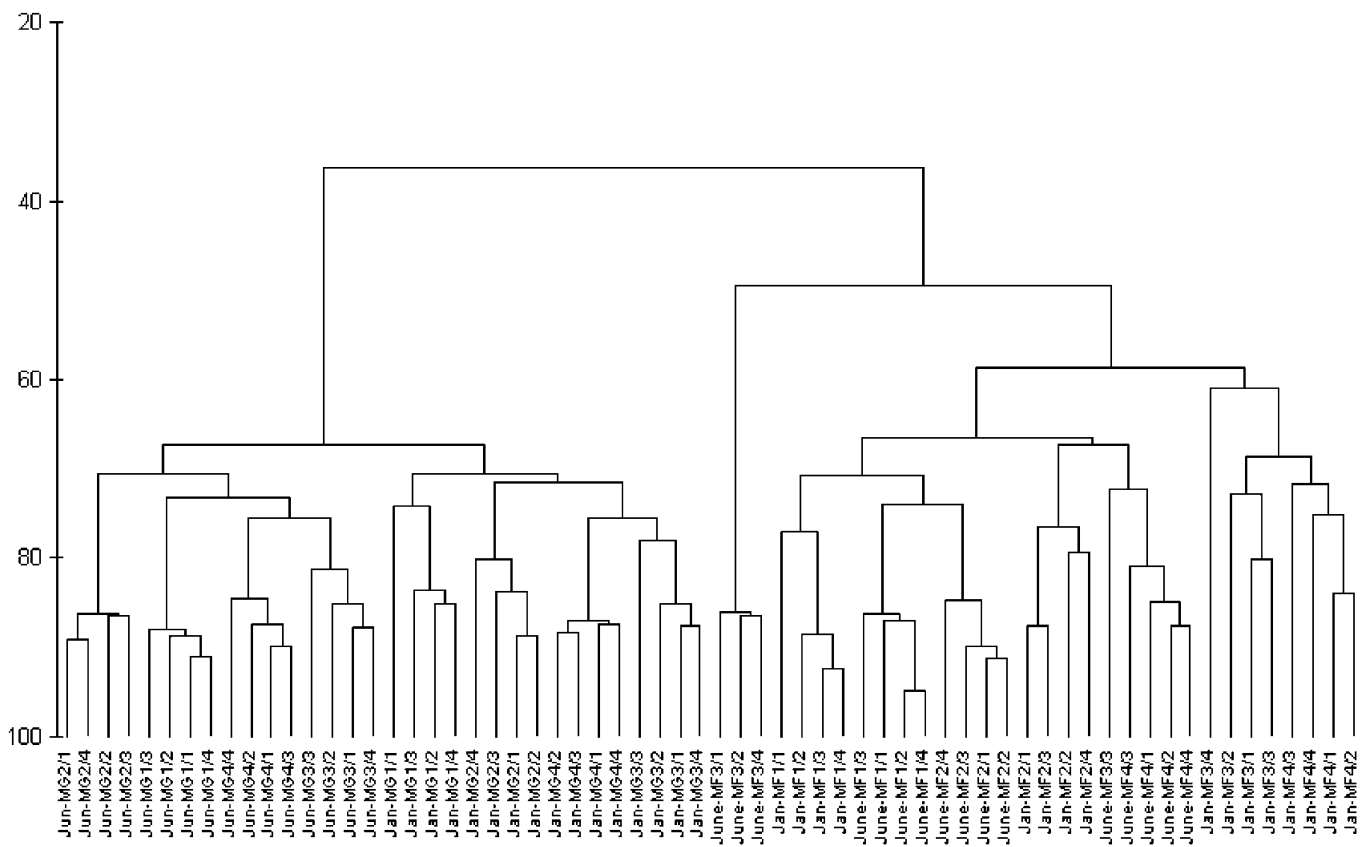

Fig. 5. Dendrogram pattern for nematode at the western Thachin River mouth, Samut Sakhon. Each sampling unit had particular stations and season, and these units were divided into two groups at 50 percent similarity by using the group-average clustering from Bray-Curtis similarity on $\ln (x+1)$ transformed abundance. 
In Habitat: In total, 52 genera in 21 families were present with 476 ind. $10 \mathrm{~cm}^{-2}$ of mean total density. In the mudflat habitat, 32 genera in 18 families were found while mean total density was 430 ind. $10 \mathrm{~cm}^{-2}$. A higher value of mean total density, 522 ind. $10 \mathrm{~cm}^{-2}$ with 50 genera in 21 families, was observed in the mangrove habitat. The results of the present study agree with similar studies conducted in the adjacent area. Jittanoon (2004) studied at Samut Songkhram, and the results showed that the number of species and density were higher in the mangrove habitat than those in the mudflat habitat. The total number of species was 59 genera with the mean total densities inhabiting the mangrove and mudflat were 460 ind. $10 \mathrm{~cm}^{-2}$ and 105 ind. $10 \mathrm{~cm}^{-2}$, respectively. Mangrove may have a wide variety of microhabitats. Thus, the difference and complication of the habitats may provide more opportunities for high number of organisms to live there. On the other hand, current speed and wave action in intertidal zone may affect organisms in the mudflat area. Meiofauna normally rely on small place between sedimentary particles. The vertical distribution is quite shallow depending on the depth of oxidized layer. The mudflat is exposed during low tide and wave action in surf zone may play an important role to characterize the nematode communities. Organisms are, in general, well adapted to cope with wave turbulence so as to resist the stresses at high energy of wave action where they live (Newell, 1970). Due to exposure to air and wave actions during low tide, the number of nematode was less in the mudflat area than in the mangrove area. Consequently, current speed, in combination with wave action, plays an important role in the mudflat habitat. Particularly in the intertidal surf zone, wave turbulence greatly causes rough movement. As a result, sediment may be relocated from place to place both in vertical and horizontal direction. Such movements decrease the physical stability of the bottom sediment as well as biological stability of the benthic community. The reduction of nematode population may be due to mortality or they may be washed and transferred into open and deeper waters. Therefore, wave action can be regarded as an important tool for distribution of organisms, as described by Fleischack and Freitas (1989) that wave current was the most important factor influencing the benthic fauna distribution. Another factor affecting the nematode community may be the concentration of organic matters. Generally, organic matters were $8.69-16.30$ percent of dry weight in the mangrove habitat and $6.61-7.45$ percent of dry weight in the mudflat (Sawangarreruks et al., 2009; Vong-in et al., 2008). The nematodes feed on organic matter and detritus, and they play important roles in decomposing organic matters that are recognized to be energy source in food web and to increase productivity and health of mangrove ecosystem. In general, benthic nematode fauna plays an important role in food web as the secondary producers to provide food to higher trophic level. The results are in line with the studies of Jittanoon (2004) and Monthum (2002) that the high numbers of nematode were related with high organic matters.

The density of nematode was high at station MF1 and MF2 in the mudflat habitat probably due to their location (Fig. 3). The stations were located far from the incoming waves and tidal current than station MF3 and MF4. Particulate organic matters tend to deposit more in the calm wave and tidal currents on the bottom. The increase of organic nutrient has led to increase the number of organisms. Our results suggest that some nematodes, such as Hopperia sp. and Sabatieria sp., were productive and rapidly increased due to high value of organic matters. Mirto et al. (2002) and Monthum (2002) found that some nematodes rapidly grew when organic matters increased. Another reason may be an effect of low oxygen. Normally, anoxia and acidic condition will occur in exceedingly high organic condition. There are unusual situation in the case of bacteria using oxygen to consume organic matters. Daptonema sp. can be tolerant to low oxygen environment and supported a high number of Daptonema nematode. Human activities are one important factor in coastal area. In particular, sediment disturbance by local villagers was observed in station MF3 and MF4 to harvest cockle during ebb tide.

Comparison of nematode compositions in both habitats showed that the nematode belonged to different groups of genus. At least 20 genera were recorded in mangrove habitat, and not in mudflat habitat (Appendix 1). The other two genera, Syringolaimus and Linhomoeus, were present in mudflat. 
Differences in the nematode composition between the mudflat and mangrove habitats may be due to biotic and abiotic factors. There were considerable differences in the sampling areas, the number of individuals collected and frequency of collection in each season. Further monitoring of nematode community structure along coastline should be carried out for a long term in order to clarify environmental changes.

Between Seasons: Composition and distribution of the benthic community depends on the affected inhabiting area. In the mudflat habitat, mean density was significantly lower $(p<0.05)$ in the dry season than the wet season, 289 and 570 ind. $10 \mathrm{~cm}^{-2}$, respectively. However, the number of species was similar in both seasons. Environmental factors changed between seasonal periods, particularly salinity were broadly ranged between $0.7-29.3$ psu between seasonal periods (Wattanajung et al., 2009). Salinity may have played the main factor affecting the change of nematode community while the other factors may have played minor roles. Density of Daptonema sp1. increased from 61 ind. $10 \mathrm{~cm}^{-2}$ in northeast monsoon to 312 ind. $10 \mathrm{~cm}^{-2}$ in southwest monsoon. Daptonema might be adapted to salinity changes and low oxygen. But the others were narrowly increased/decreased in number. In contrast, the number of species and density were higher in the dry season than the wet season in the mangrove habitat. The values were 575 ind. $10 \mathrm{~cm}^{-2}$ and 45 genera in dry season and 469 ind. $10 \mathrm{~cm}^{-2}$ and 37 genera in wet season. Although the density of nematode was significantly different between the wet and dry seasons $(p<0.05)$, the difference was substantially smaller in the mangrove than the mudflat habitat. Presence of microhabitat and complicated structure may have mitigated the seasonal effect in the mangrove habitat.

\section{Community Structure of Nematode}

The nematode community structure in mangrove habitat was more diverse than in the mudflat habitat in term of the number of species and density. The mangrove habitat showed high diversity index and slight change in evenness index. The diversity index ranged between $2.18-2.78$, and the evenness index was $0.75-0.95$. In the mudflat habitat, the diversity and evenness index of nematode community fluctuated between $0.66-2.08$ and $0.23-0.71$, respectively. The results showed similar patterns to the previous studies by Jittanoon (2004) in the upper gulf of Thailand. However, her study did not clearly indicate the nematode community structure in the mudflat habitat.

The MDS and Bray-Curtis similarity analysis showed clear division of nematode communities into the mangrove and mudflat habitat. The community structure might be controlled by different physical and chemical factors in each habitat. The nematode community structure in mangrove was changed slightly between the seasonal periods while the community in the mudflat was disturbed by natural turbulence and human activities. The study of benthic communities is a particularly useful and sensitive tool for identifying sediment related stress (Alongi, 1990). This study provides a base line data for future comparison on the change of meiofauna community structure that could be a useful tool detecting and monitoring the biological effects of marine disturbance at Thachin Rriver mouth.

\section{Acknowledgments}

The authors thank the staff of Marine and Coastal Resource Research Center, the Upper Gulf of Thailand, for their help on sampling operation. Thanks to Ms. Tipmas Srisombat for her help to identified nematode samples. We are also thankful to anonymous reviewers for their comments and correction of the manuscript. Finally, we also wish to acknowledge the Department of Marine and Coastal Resources for providing some grant that made it possible for study. Publication of this paper is financially supported in part by Natural Geography In Shore Areas (NaGISA) and Ministry of the Environment Japan (The Environment Research and Technology Development Fund S-9). 


\section{References}

Alongi, D.M. 1990. Community dynamics of free-living nematodes in some tropical mangrove and sandflat habitats. Bulletin of Marine Science, 46 (2): 358 - 373.

Alongi, D.M., D.F. Boesch and R.J. Diaz. 1983. Colonization of meiobenthos in oil-contaminated subtidal sands in the lower Chesapeake Bay, Marine Biology, 72: 325 - 335.

Chou, L.M., J.Y. Yu and T.L. Loh. 2004. Impcts of sedimentation on soft-bottom benthic communities in the southern islands of Singapore. Hydrobiologia, 515: 91 - 106

Fleischack, P.C. and A.J. de Freitas. 1989. Physical parameters influencing the zonation of surf zone benthos. Estuarine, Coastal and Shelf Science, 28: 517-530.

Harkantra, S.N. 1982. Studies on sublittoral macrobenthic fauna of the inner Swansea Bay. Indian Journal of Marine Science, 10: 75 - 78.

Jittanoon, C. 2004. Marine nematode communities in coastal mangrove areas of the inner gulf of Thailand. Master of Science, Department of Marine Science, Kasetsart University, Bangkok. 151 pp. (in Thai with English abstract).

Mirto, S., T. La Rosa, C. Gambi, R. Danovara and A. Mazolla. 2002. Nematode community response to fish-farm in the western Mediterranean. Journal of Environment Pollution, 116: 203 - 214.

Monthum, Y. 2002. Free-living marine nematodes community at the mouths of the canals around Khung Krabaen, Chanthaburi Province. Master of Science, Department of Marine Science, Kasetsart University, Bangkok. $158 \mathrm{pp}$. (in Thai with English abstract).

Newell, R.C. 1970. Physical, chemical and biological features of the intertidal zone. In: Biology of intertidal animals. Logos Press Limited, London, UK. pp. 1 - 46.

Round, P.D. 2006. Shorebirds in the Inner Gulf of Thailand, Stilt $50: 96$ - 102.

Sawangarreruks, S., P. Yaowasooth, N. Lertkasetvittaya, W. Thongdeeying, N. Silpasarn and W. Vong-in. 2009. Macrobenthic fauna at Thachin mud flat river mouth, Samut Sakhon. Journal of Fisheries Technology Research, 3 (1): 173 - 186. (in Thai with English abstract).

Talawat, J., P. Weerawat, P. Laongmanee, S. Kajonwattanakul and C. Singhrachai. 2004. Monitoring on density and distribution of meiofauna in the Pakklong Sub-district coastal area. Southeast Asian Fisheries Development Center. TD/RES/93 LBCFM-PD No. 36, pp. 35.

Tsutsumi, H. 1987. Population dynamics of Capitella capitata (Polychaetea; Capitellidae) in an organically polluted cove. Marine Ecology Progress Series, 36: 139-149.

Tsutsumi, H. 1990. Population persistence of Capitella sp. (Polychaetea; Capitellidae) on a mud flat subject to environmental disturbance by organic enrichment. Marine Ecology Progress Series, 63: 147-156.

Vong-in, W., N. Silpasarn, P. Yaowasooth, P. Phenpraphai, W. Thongdeeying and W. Saowarit. 2008. Species and distribution of mangrove crabs at the Thachin river mouth, Samut Sakhon Province. Journal of Fisheries Technology Research, 2 (2): 115 - 124. (in Thai with English abstract).

Wattanajung, T., W. Gosapon, K. Long-ampai and W. Niyomthai. 2009. Coastal water quality at Thachin river mouth, Samut Sakhon Province. In: National Marine Science Conference, 25 - 27 August 2008, Department of Marine and Coastal Resources, Phuket.pp. 318-326. 